\title{
RURAL AREAS OF CRIMEA: AN IMPORTANT OBJECT OF HUMAN GEOGRAPHY RESEARCH
}

\author{
Kateryna BESIEDINA
}

\author{
Institute of Geography, National Academy of Science of Ukraine \\ besedinakateryna@gmail.com
}

\begin{abstract}
The essence of human geography research of rural ARC has been disclosed. Priority trends of this problem study were analyzed in theoretical-methodological and resource-functional areas. We have considered features of economic activity, social and demographic processes of rural areas of Crimea, and defined strategic directions of further study.

Key words: rural areas, Crimea, economic activity, recreational potential.
\end{abstract}

UDC: $911.3: 631(447.75)$

\section{СІЛЬСЬКА МІСЦЕВІСТЬ АР КРИМ - ВАЖЛИВИЙ ОБ'ЄКТ СУСПІЛЬНО-ГЕОГРАФІЧНИХ ДОСЛІДЖЕНЬ}

\author{
Катерина БЕСЄДІНА
}

Інститут географії Національної академії наук України besedinakateryna@gmail.com

\begin{abstract}
Анотація: Розкрито суть суспільно-географічних досліджень сільської місцевості АРК. Проаналізовано пріоритетні напрями вивчення даної проблеми в теоретико-методологічному та ресурсно-функціональному вимірах. Розглянуто особливості господарської діяльності, соціальних та демографічних процесів сільських територій, окреслено стратегічні напрями подальшого вивчення сільських територій АРК.
\end{abstract}

Ключові слова: сільська місцевість, АРК, господарська діяльність, рекреаційний потенціал.

удк: 911.3:631(447.75)

Вступ. Постановка проблеми. Вивчення сільської місцевості є одним 3 важливих напрямів суспільно-географічних досліджень АРК. Від рівня розвитку сільської місцевості залежить продовольча безпека країни, ефективність агропромислового комплексу, раціональна територіальна організація виробництва і розселення населення, стабільність розвитку регіонів. Дослідження сільської місцевості АР Крим з суспільно-географічних позицій мають бути спрямовані на вирішення завдань соціального відродження села, основними $з$ яких є нарощування обсягів агропромислового виробництва, розвиток ринкових форм господарювання, забезпечення випуску конкурентоспроможних продовольчих товарів. Актуальність вивчення цих питань також пов'язана $з$ кризовим станом сільського господарства, високою соціальною напругою на селі, гостротою демографічних, медичних та екологічних проблем, характерних для сільської місцевості. Істотні зміни відбуваються в АРК, у т.Ч. в сільській місцевості у зв'язку 3 анексією цього регіону Російською Федерацію. Особливо важливими $є$ регіональні дослідження сільської місцевості із суспільногеографічних позицій в економічному, соціальному, природно-екологічному аспектах 3 урахуванням місцевих умов і територіальних відмінностей. Такі дослідження дають можливість виявити вплив сучасних процесів, що відбуваються в економічній системі господарювання, спеціалізації виробництва,

(C) К. Бесєдіна факторах землегосподарювання та стан сільської місцевості і життєдіяльності населення в кожному конкретному регіоні. Це є основою при обгрунтуванні напрямів розвитку сільської місцевості, підвищенню ефективності господарської діяльності, збільшенню зайнятості і покращенню якості життя сільських мешканців.

Аналіз останніх досліджень і публікацій. Переважна більшість досліджень, присвячених АПК і сільській місцевості АРК, висвітлюються в роботах таких авторів, як М.В.Додонова, Ф.В.Зінов'єв, К.М.Османов, С.Я.Дементьєва та ін. В них аналізується структура і спеціалізація господарської діяльності, ефективність виробництва, приватне господарювання на селі тощо. У працях економіко-географів Г. В. Балабанова, Р. Р. Абкадирова, О. М. Кузьміної та ін. розглядаються питання відтворення населення, вплив зовнішньоекономічних зв'язків на розвиток АПК, сільськогосподарське природокористування у цьому регіоні, господарські типи освоєння земель Криму тощо. Значно менше уваги приділено власне розвитку сільської місцевості, її особливостям в АР Крим.

Формулювання цілей статті. Постановка завдання. Головною метою даного дослідження $\epsilon$ визначення сільської місцевості АРК як об'єкта суспільно-географічних досліджень. Головними складовими є господарська діяльність і зайнятість населення, рівень життя і територіальні відмінності у розвитку сільської місцевості.

Важливим також є аналіз методики вивчення 
сільської місцевості АРК яка має бути спрямована на вирішення завдань соціального відродження села, основними 3 яких $є$ нарощування обсягів агропромислового виробництва, розвиток ринкових форм господарювання, забезпечення випуску конкурентоспроможних продовольчих товарів [15].

Виклад основного матеріалу. Сільська місцевість АРК визначається як історично сформована частина поселенської мережі, в якій поєднуються сільські населені пункти, жителі яких переважно зайняті у сільському господарстві [13]. Однак значна частина сільського населення зайнята в інших видах виробничої діяльності - рекреаційна діяльність, рибне господарство, добувна промисловість, будівництво та ін.

На сільські райони тут припадає 37,3\% населення, хоча за площею вона займає 69\% території. У сільському господарстві виробляється (2012 р.) 6665,0 млн грн., або 17,4\% від всього ВВП регіону [14]. Важливими об'єктами дослідження сільської місцевості АРК, що є системоформуючими для розвитку економіки, зайнятості сільського населення, його міграційної активності є природноресурсний i трудовий потенціал, демографічна ситуація, загальний стан соціально-економічного розвитку АРК [13].

Особливості

соціально-економічного розвитку Криму, у тому числі сільської місцевості, визначаються його приморським розташуванням, великою протяжністю берегової лінії, наявністю земельних ресурсів, різноманіттям природних умов і ландшафтів, потужним рекреаційним потенціалом, що формує великий попит на сільськогосподарську продукцію; відносно теплим кліматом, однак нестачею вологи. На ці особливості накладаються господарські традиції місцевого населення різних етносів, що в сукупності формує основу господарського комплексу Криму і зокрема сільської місцевості.

Одним 3 важливих елементів дослідження сільської місцевості АР Крим є природні, екологічні та історичні чинники її розвитку. Головними $з$ них є: грунтово-кліматичні умови і ландшафтні особливості регіону; економічна система господарювання; економіко-географічне положення півострова i зокрема сільської місцевості; особливості розселення населення, розвиток рекреації, етнічний чинник. Їх вивчення дає змогу визначити характерні риси розвитку сільської місцевості, напрями господарської діяльності ізайнятості населення у сільських районах, можливості диверсифікації виробництва, регіональні відмінності в розвитку сільської місцевості. Основна увага має бути звернена на сільське господарство i розвиток АПК, зважаючи на особливості грунтовокліматичних умов і великий попит населення на продовольчу продукцію - місцевого населення і в районах рекреації $[2,8,12]$.

Слід зазначити, що в сільській місцевості АРК $\epsilon$ значний природно-ресурсний i економічним потенціал для розвитку несільськогосподарських видів господарської діяльності (видобування корисних копалин, вилов риби та добування інших водних живих ресурсів, транспортне обслуговування рекреантів, транспортне обслуговування населення, будівництво, розвиток логістики, соціальна сфера тощо) [1].

Великий вплив на розвиток сільської місцевості i зайнятості населення справляє етнічний чинник. Головними етносами, що формують виробничий профіль і спеціалізацію господарської діяльності в сільській місцевості АРК, $€$ український, кримськотатарський і російський. Кримськотатарське населення надає перевагу виноградарству, садівництву, овочівництву, а також вівчарству. Господарська діяльність українців пов'язана 3 розвиткомземлеробства, особливоустеповомуКриму, зокрема зерновим господарством, виробництвом продовольчих товарів, овочів та фруктів [6].

Головними складовими природно-ресурсного потенціалу, що впливають на розвиток сільської місцевості, є: а) земельні ресурси; б) водні ресурси; в) мінерально-сировинні ресурси; г) рекреаційні ресурси; г) запаси риби та інших водних організмів; д) лісові ресурси.

Суспільно-географічна оцінка кожного виду ресурсу має бути спрямована на визначення можливостей їх залучення до господарської діяльності у сільській місцевості, створення робочих місць, виробництво продукції за інноваційною моделлю розвитку.

Найважливішими для сільської місцевості АРК є земельні ресурси. Особливе значення має структура земельного фонду, тобто використання землі як засобу виробництва в умовах Криму - землі цього регіону, особливо у степовій частині через посушливий клімат, недостатність зволоження потребують зрошення. Особливо важливою є наявність сільськогосподарських угідь - ріллі, сіножатей, пасовищ, багаторічних насаджень, що використовуються в сільському господарстві [5]. Площа сільськогосподарських угідь становить 69 \% загального земельного фонду АРК, з них на ріллю припадає 70,1\%, сіножаті і пасовища - 0,2\%, багаторічні насадження - 29,4\%. Площа зрошуваних земель у 2012 році становила 7,3\%, останнім часом вона скоротилася до $0,8 \%$, що істотно вплинуло на спеціалізацію сільського господарства та його економічну ефективність [14]. Слід звернути увагу на якісну оцінку земель, що включає вміст гумусу, наявність еродованих, засолених, солонцюватих грунтів.

Слід зазначити що, грунти Криму різноманітні: на рівнинах переважають чорноземи, у Присивашші - каштанові, в комплексі з солончаками і солонцями;, на схилах гір - бурі, гірсько-лісові; на Південному березі - коричневі. Ірунтовий покрив $є$ особливо важливим об'єктом дослідження, оскільки значно впливає на господарську діяльність і зокрема сільське господарство у різних районах. Найкращі грунти зосереджені у північній та центральній частинах АРК, однак вони потребують зрошення $[1,4]$. Саме за умов зрошення тут можливе вирощування зернових, овочевих, технічних і кормових культур, що є основою спеціалізації рослинництва. Надмірне навантаження 
на земельні ресурси, пов'язане з функціонуванням Північно-Кримського каналу, стало причиною активного прояву негативних процесів (ерозія грунтів, суфозійно-просадочні процеси, карст, площинний змив, засолення та підтоплення грунтів) [11]. Нині цей процес посилюється через буріння надмірної кількості артезіанських свердловин. Використання зрошуваних земель потребує особливої уваги 3 економічних та екологічних позицій, ефективності виробництва сільськогосподарської продукції $[9,16]$.

Особливо актуальним для Криму $є$ його водозабезпеченість, що суттєво впливає на розвиток сільського господарства і життєдіяльність населення. Порівняно невелика кількість атмосферних опадів, тривале посушливе літо, поширення у горах карсту зумовило брак поверхневих вод [10]. Ведення сільського господарства можливе тільки за умов зрошення, яке поширене по всій частині рівнинного Криму (основні райони - Первомайський, Красногвардійський, Нижньогірський, Совєтський тощо). Важливими напрямами дослідження $є$ забезпечення водою сільського населення, визначення обсягів та рівня очищення стічних вод; оцінювання масштабів меліоративних робіт тощо.

Серед мінерально-сировинних ресурсів найбільше значення для сільської місцевості мають поклади будівельної сировини - вапняк будівельний, крейда, пісок тощо. Основні видобувні підприємства розташовані в Бахчисарайському та Сімферопольському районах [7, 10].

Запаси риби та інших водних організмів мають важливе господарське значення для прибережних сільських територій, особливо Ленінського району, де зосереджені основні риболовецькі комплекси, включи консервні заводи [1].

Необхідно дослідити рівень заліснення (лісистості) території землекористування та провести аналіз характеру їх господарського використання. Лісом покрито 10\% території Криму. У Гірському Криму ліси є переважаючим типом рослинності і займають площу біля 255,7 тис. га, що складає $36 \%$ території регіону [11]. Особливості видового складу цих лісів обумовлені, в першу чергу, географічнім розміщенням Криму, особливостями рельєфу та близькістю моря. На території сільської місцевості Бахчисарайського, Сімферопольського, Білогірського районів зосереджені невеликі площі лісі, що дає можливість рубки головного користування (вирубування стиглих деревостанів 3 метою заготівлі деревини).

Використання цих ресурсів дає змогу диверсифікувати зайнятість сільського населення, збільшити його статки.

Важливим об'єктом суспільно-географічних досліджень АРК 3 позицій розвитку сільської місцевості $€$ рекреаційні ресурси $і$ розвиток рекреаційних послуг. Ця сфера діяльності впливає на розвиток сільської місцевості в таких напрямах: по-перше, навколо цих районів формується масовий попит на сільськогосподарську продукцію - хліб і хлібні продукти, яйця, овочі, баштанні, a також дієтичну продукцію, що $є$ технологічно малотранспортабельною

(незбираномолочна продукція, свіже м'ясо, ягоди, фрукти тощо); по-друге - частина сільського населення зайнята в рекреаційній діяльності в державному й індивідуальному секторах, що створює особливо в сезонний період можливості суттєвого підвищення доходів населення. Дослідження рекреаційної діяльності північних та східних районів є важливими з позицій розвитку зеленого туризму. Цьому сприятиме атрактивність сільських ландшафтів, етнічне різноманіття господарської діяльності, культурна спадщина цих районів тощо [17].

Важливою складовою суспільно-географічного дослідження сільської місцевості АР Крим є вивчення демографічних проблем. Головна увага має бути звернена на динаміку кількості населення його вікову структуру, міграційні рухи, стан сільських поселень, освітній, професійний і соціальний склад, здоров'я населення, рівень забезпечення професійними кадрами тощо. Демографічні і міграційні процеси є важливими чинниками розвитку сільської місцевості, вони формують основу господарської діяльності, особливо розвитку сільського господарства і АПК, впливають на економічний розвиток села, збереження виробничих і культурних традицій селян.

На сільське населення АР Крим припадає 32,1\%, воно розміщується у 980 сільських населених пунктах. Демографічна ситуація у сільській місцевості характеризується негативними тенденціями впродовж 5 років (2008-2013 рр.) сільське населення зменшилось на 20\%, смертність перевищує народжуваність, продовжується процес постаріння населення. Відбувається відтікання сільських мешканців у міста, що пов'язано з безробіттям i обмеженими можливостями працевлаштування тощо.

Зайнятість населення сільської місцевості залежить від наявності сфер прикладання праці, мотивації працюючих, кваліфікаційного і професійного складу населення. Значно впливає етнічний чинник - відбувається розподіл господарської діяльності згідно 3 наявністю етнічних груп у різних сільських поселеннях.

Одним із ключових питань дослідження сільської місцевості $€$ виробнича діяльність і зайнятість населення сільських мешканців. Основою виробничої діяльності АРК є сільське господарство і розвиток АПК. Головними питаннями дослідження сільського господарства є: спеціалізація галузі, включаючи рослинництво і тваринництво; ефективність виробництва основних видів продукції; організаційно-правові форми господарювання; особливості землегосподарювання; агровиробничий потенціал земельних ресурсів; рівень розвитку природоохоронних заходів тощо. Великого значення набуває аналіз форм господарювання, визначення ролі великотоварного виробництва (агрохолдинги) у розвитку сільського господарства і частки особистих селянських господарств у виробництві аграрної продукції.

Сільськогосподарська спеціалізація сільської місцевості АР Крим потребує аналізу ефективності 
ведення сільського господарства, вивчення формування сільськогосподарських угідь і територій сівозмін, відповідності їхньої структури агровиробничому потенціалу грунтів, ефективності вирощування культур та грунтовідновних і грунтоохоронних заходів тощо. В структурі сільського господарства переважає рослинництво, на яке припадає 50,9\% валової продукції, тваринництво - 49,1\% [14]. Галузями спеціалізації сільського господарства АР Крим є зернове господарство, виноградарство, садівництво, овочівництво. Треба відзначити також ефіроолійне виробництво, яке є традиційною галуззю для АРК, основою ефіроолійної та лікарської сировини є шавлія, лаванда, троянда. У тваринництві виділяються молочно-мясне скотарство, птахівництво, свинарство. Сільське господарство є важливим об'єктом дослідження тому що це основа господарської діяльності сільської місцевості, яка є важливою ланкою розвитку через своє продовольче значення.

Провідними галузями харчової промисловості АРК є виноробна, плодоовочеконсервана, тютюнова, м'ясна, маслоробна і молочна, комбікормова.

У дослідженні екологічних проблем головними є : деградація грунтів, розвиток таких несприятливих процесів як дегуміфікація, зменшення родючості, зростання частки кислих, вторинно-заболочених, засолених, забруднених, еродованих грунтів; погіршання стану осушених та зрошуваних земель. Слід зазначити, що на якість грунтів значно вплияє вирощування такої грунтовиснажливої культури як соняшник, площі якої займають 70,6 тис. га $[3,14]$.

3 цих позицій варто дослідити участь сільської місцевості в зовнішньоекономічній діяльності. Найбільші показники експорту мають Сімферопольський та Красноперекопський район, де сільська місцевість $є$ важливо ланкою у виробництві сільськогосподарської експортної продукції (м'ясомолочні продукти, зернові та овочеві культури, продукція птахівництва).

Розглядаючи проблеми розвитку сільської місцевості слід вивчити життєвий рівень населення, стан соціальної інфраструктури, потенціал трудових ресурсів, рівень здоров'я населення, криміногенну ситуацію тощо. Важливими складовими дослідження $\epsilon$ рівень безробіття, динаміка захворюваності сільського населення Серед соціальних проблем сільської місцевості АРК особливо виділяється проблема міграції молоді, зменшення чисельності працездатного населення, наявність і стан об'єктів соціальної інфраструктури (шкіл, дитячих садків, лікарень тощо). Рівень безробіття в сільській місцевості складає 49,6\%, рівень заробітної плати - 2654 грн, що є середнім показником по Україні. Забезпеченість сільського населення житлом - 18, 2 $\mathrm{M}^{2}$ загальної площі.

На 2012 рік в АРК нараховувалось 1042 села, 3 них 77 сіл з населенням до 50 осіб, 89 сіл 3 населенням до 100 чоловік і 374 села 3 населенням до 500 осіб. Згідно з статистичними даними в Криму відбулося знелюднення 11 сіл (2012 рік), причиною якого була міграція працездатного населення через нестачу робочих місць, що є суттєво проблемою сільської місцевості.

Велике значення для сільських районів має такий чинник, як доступність сільськогосподарських підприємств до локальних та регіональних центрів збуту продукції, це особливо стосується обслуговування курортних районів в літній сезон. Не менш важливим є доступність до магістральної транспортної інфраструктури, врахування витрат на перевезення продукції тощо. В сільській місцевості АРК найбільша частка вантажоперевезень припадає на автомобільний транспорт - 16,5 млн. т. Загальна протяжність автомобільних доріг становить 6,7 тис. км, густота збільшується від центральних районів півострова до узбережжя. Важливу роль відіграє також залізничний транспорт, який об'єднує АРК 3 материком, найважливішими коридорами є Джанкой-Сімферополь і Джанкой-Керч. Морський транспорт забезпечує внутрішньорегіональні та міждержавні зв'язки, основу вантажообігу складає зерно та продукти видобувної промисловості.

Досліджуючи сільську місцевість АРК слід звернути увагу на центри розвитку сільських районів (це переважно малі і середні міста): Сімферопольський - машинобудування, харчова, легка, промисловість будівельних матеріалів; Севастопольський - суднобудування, приладобудування, рибна, виноробна, промисловість будівельних матеріалів; Керченський - гірничо-металургійна, рибна, суднобудування, промисловість будівельних матеріалів; Красноперекопський - виробництво основної хімії та Джанкойський - машинобудування і харчова промисловість. Основну частину в структурі займає переробна промисловість $86,5 \%$, добувна - 6,1 \%, виробництво і розподіл електроенергіï, газу, води - 7,4 \% [14].

Висновки і перспективи подалыших розвідок. Основну роль у розвитку сільської місцевості АРК і зокрема господарської діяльності відіграє економічна система: принципи, за якими регулюються дії державних структур щодо розвитку сільської місцевості, АПК, а також суб'єктів господарювання. Вони створюють умови для виробництва і реалізації сільськогосподарської продукції, організації сільськогосподарських споживчих ринків, розвитку експорту тощо. Для сільської місцевості АР Крим є важливим створення законодавчої та нормативноправової бази, яка регламентувала б розвиток аграрної сфери, 3 урахуванням статусу АРК як рекреаційного регіону. Велике значення мають створення фермерських та інших видів господарюючих суб'єктів на селі, розвиток приватного підприємництва. Виконання розроблених у свій час програм розвитку АРК (проекти ПРООН Проект «Підтримка регіонального розвитку Криму», проект «Сталий розвиток у Криму: моделі перетворення сільських територій та консультативні послуги» тощо) дадуть змогу підвищити ефективність галузей сільського господарства та АПК, підвищити рівень розвитку села i життєдіяльності сільського населення цього регіону. 
Головними стратегічними напрямами суспільногеографічних досліджень сільської місцевості є:

- вивчення характерних особливостей сільської місцевості АР Крим, визначення конкурентоспроможності сільського господарства регіону;

- обгрунтування із суспільно-географічних позицій пріоритетного розвитку сільської місцевості в економіці регіону; вивчення структури, спеціалізації, територіальної організації господарської діяльності сільської місцевості 3 урахуванням можливостей природно-ресурсного потенціалу, наявності трудових ресурсів, стану демографічної ситуації тощо;

- узгодження економічних, соціальних та екологічних проблем розвитку сільської місцевості 3 урахуванням суспільно-географічних чинників;

- вивчення регіональних відмінностей розвитку сільської місцевості з метою вироблення ефективної регіональної політики держави.

\section{References:}

1. Bagrov N. V., Rudenko L. G. Atlas Avtonomnoj Respubliki Krym [Atlas of the Autonomous Republic of Crimea]. Kyiv-Simferopol, 2003, 80 p. (In Ukrainian and Russian).

2. Balabanov G. V., Nagìrna V. P., Nižnik O. M. Transformaciâ strukturi gospodarstva Ukraïni: regìnal’nij aspekt [Transformation of the economic structure of Ukraine: regional aspect]. Kyiv, 2003, 404 p. (In Ukrainian).

3. Bokov V. A. Transformaciâ struktury vodnogo balansa v Krymu v XX veke - načale XXI i ë̈ optimizaciâ [Transformation of Crimean water balance structure in the twentieth - early twenty-first centuries and its optimization]. Simferopol, 2011, 193 p. (In Ukrainian).

4. Ivanov V. N. Počvy Kryma i ih melioraciâ [Soils of Crimea and their melioraton]. Simferopol, 1976, 64 p. (In Russian).

5. Krymologiâ. Prirodno-resursnyj potencial poluostrova [Krymologiya. Natural resource potential of the peninsula]. Access mode: http://krymology.info/index.php (in Russian).

6. Libanova E. M., Kurilo İ. O., Stešenko V. S. Naselennâ Ukraïni. Social'no-demografičnì problemi ukraïns'kogo sela [The population of Ukraine. Socio-demographic problems of the Ukrainian village]. Kyiv, 2007, 468 p. (In Ukrainian).

7. Mineral'nye resursy Kryma i prilegaûŝej akvatorii Černogo i Azovskogo morej [Mineral resources of the Crimea and adjacent waters of the Black and Azov Seas]. Atlas / Priloženie k naučno-praktičeskomu diskussionnoanalitičeskomu sborniku "Voprosy razvitiâ Kryma" [Atlas / 8. Annex to scientific and practical discussion and analytical collection "Problems of development of the Crimea"]. Simferopol, 2001, 80 p. (In Russian).

9. Nagìnna V. P. APK Ukraïni - važlivij ob'êkt doslìdžen' akademičnoï geografičnoï nauki (sut', retrospektiva, strategìčnì naprâmi) [Agroindustrial complex of Ukraine as an important research object of academic geography (essence, retrospective, strategic directions)]. İstoriâ ukraïns'koï geografï̈ [History of Ukrainian geography], Ternopil, 2002, Vol. 5, pp.72-77 (In Ukrainian).

10. Orošenie stepnogo Kryma [Irrigation of the Steppe Crimea]. Access mode: http://trademaster.ua/finance/738 (In Russian).

11. Pozačenûk E. A. Vodnye resursy $i$ vodnoe hozâjstvo Kryma [Water resources and water management in Crimea]. Simferopol, 2003, 107 p. (In Russian).

12. Podgorodeckij P.D. Krym: Priroda [Crimea: Nature]. Simferopol, 1988, 192 p. (In Russian).

13. Râbokon' V. P. Osnovnì naprâmi socìal'no-ekonomì̌noï perebudovi ta rozvitku ukraïns'kogo sela [Main directions of socio-economic reconstruction and development of Ukrainian village]. Ekonomika APK [Economy of agroindustrial complex], 2008, Vol.6, pp. 86-89 (In Ukrainian).

14. Rogožin O. G. Demografični perspektivi ukraïns’kogo sela: istorični peredumovi, regìnal’nij analiz i modelûvannâ [Demographic prospects for Ukrainian village: historical background, regional analysis, and modeling]. Kyiv, 2004, 296 p. (In Ukrainian).

15. Statističnij ŝoričnik Avtonomnoï Respubliki Krim za 2012 rìk [Statistical Yearbook of ARC in 2012]. Golovne upravlinnâ statistiki v AR Krim [Department of Statistics in Crimea]. Simferopol, 2013, 545 p. (In Ukrainian).

16. Topčiêv O.G. Suspil'no-geografičnì doslidžennâ. Metodologiâ, metodi, metodiki: Navčal'nij posibnik [Sociogeographic research. Methodology, methods, techniques: Textbook]. Odessa, 2009, 632 p. (in Ukrainian).

17. Ustojčivyj Krym. Vodnye resursy [Steady Crimea. Water resources]. Simferopol, 2003, 416 p. (In Russian)

18. Zelenij turizm âk rìnovid pidpriêmnic'koï diâl'nostì v sil's'kij miscevostì [Green tourism as a form of entrepreneurship in rural areas]. Access mode: http://tourlib.net/statti_ukr/korobka2.htm (In Ukrainian). 